\title{
The Education of the Librarian ${ }^{*}$
}

\author{
Dr. Leyh retired as director of the uni- \\ versity library at Tübingen.
}

$\mathrm{T}$ HE THEME that I have chosen can to a degree serve as the fundamental basis of our profession: it is the question of the education of the librarian. I refer not solely to what he learns in the classroom, the training in courses and lectures and the taste for knowledge but also to his education, an intellectual attitude, described by Goethe in that well known phrase, "Geprägte Form die lebend sich entwickelt." (A form that is fixed yet full of living change.) It is the librarian's special problem to find some sort of harmonious compromise for the conflicting requirements of his personal and professional life.

Perhaps there are librarians in charge of special collections who have already reached a safe harbor. The professional workers in general libraries are like heavily laden ships which toss about in a rough sea and peer through the mist for a landmark. This is no less the case in America than it is in Western Europe. Confronted by the tremendous problems of growth and use of our collections, we ask ourselves what should we as librarians naturally stress?

Not a few of us chose the library profession because of the breadth of our interests, only to find ourselves tied to some routine task. Between these two poles of ideal and reality the profession has swung

\footnotetext{
* This address was first delivered in Stockholm on May 1949. It first appeared in print in Nordisk Tidskrift for Bok och Bibliotheksvasen, XXXVII (1950), 56-70, and was reprinted as the title essay of a collection by the author published in Copenhasen in collection by the author published in Copenhasen in graph by Ejnar Munksgaard (Library Research Monograph No. 3). The translator is indebted to Pro-
fessor Karl J. Arndt of Clark University for invaluable fessor Karl J. Arndt of Clark University for invaluable translate and print has been granted.-Albcrt $C$ Gerould, Free Library of Philadelphia.
}

in the last two thousand years, and not without reason have men spoken of the tragedy of the profession. It is simple enough to judge the merits of any other profession. Everyone knows what is meant by a gallant officer, an inspiring teacher, an impartial judge or a learned physician. But even the scholars, though they have spent their days in libraries for centuries, do not understand the training, the duties, and the accomplishments of the librarian.

That the librarian must merge in himself the qualities of the scholar, the organizer and the practical man is not perhaps entirely unknown. But all too often it is chance personal interests-not to say bias or mood, which affects the librarian's judgment. And certain objective facts add to his confusion. Now and then in the history of libraries he finds a first class scholar like Leopold Delisle or Fredrich Ritschl while at other times he finds that the librarian is just a bird of passage on his way to a career or a shipwrecked sailor seeking a snug harbor. It takes a long time for him to form a real picture of what the librarian really is.

The same uncertainty underlies any estimate of the value and purpose of libraries. To Leibnitz the library was the bringing together of the greatest spirits of all times and peoples. The poet Rilke is not the only one who speaks of purposeless museums and of libraries in which humanism is dried out like a mummy. Even the scholar complains of the dust and mustiness of these same libraries where he quarries the very foundation stones of his learning.

We should not allow ourselves to be led astray by these differing judgments. Sound judgment and objectivity have never been 
the strong suit of the scholar and to no less a man than Wilhelm von Humboldt scholars were, "of all men the most unruly and hardest to please with their eternally crisscrossing interests, their jealousy, their envy, their urge to power, their onesided judgments where each claims that his field alone deserves to be supported and promoted." But to be judged by one's peers, that is, by experts, is one of the chief rights of man. And this right we claim for libraries and particularly for librarians; let us begin with the libraries.

It was Schopenhauer who made one of the most pregnant comments about libraries when he called them mankind's only sure and living memory. It was they that saved ancient literature, and the Swiss zoologist Rütimeyer assures us that the whole of zoology would be reduced to the natural history of Aristotle if libraries and museums should suddenly vanish. These two facts alone should provide libraries with glory enough for all time. That we librarians even today are threshing no empty straw, statistics give daily proof.

As far as their custodians, the librarians, are concerned, they must follow all the movements of far-reaching modern science. For this purpose an application of intellectual energy and willpower is just as necessary as it would be for most other academic professions: an encyclopedic learning based on a thorough grounding in a special field; an unusual measure of the ability to concentrate and make decisions, in order to remain master of the ever flowing tide of books; love of order, without which all else is as nothing; and last but not least a full measure of benign human understanding in order to meet the danger, always peculiar to librarians, of dabbling in projects, "play. ing with libraries" like a dilettante. For qualities of character are perhaps more important to a librarian than are those of pure scholarship.
That the librarian is a homo sui generis had already been manifest for centuries before it was officially recognized in the last quarter of the I 9 th century by the setting up for it of admission, training and examination regulations as a profession in its own right. The librarian is an administrator without being any the less a scholar. Administrative duties and scholarly work are in competition for his time. The fundamental problem of the librarian is to give to each of these the proper importance and to keep each in a proper relation to the other.

This crisis is an old one. It was Lessing who said that he refused to make himself a stableboy and keep the horses supplied with fodder. The classic case was Jakob Grimm who felt as librarian in Göttingen like a harnessed slave. The Americans believed for a long time that they had surpassed the European libraries because of their interest in purely administrative and technical matters. Since then they have realized that administrative technique must itself be based on sound scholarship if it is to serve a useful purpose. Many library schools even there are attempting to bridge the gap between the daily task of the librarian and scholarly activity.

Things came to crisis in Germany in the years 1903-09 when representatives of quite a number of libraries issued the complaint that professional librarians were being put to work at mechanical tasks for which their scholarly preparation was quite superfluous.

The immediate development of the middle ranks of the profession was demanded and it was urged that all librarians of whatever rank should cooperate in building up their collections. Through carrying out these suggestions it was hoped to set aside all these objections. But this hope was in vain; a mere change in organization did not get at the root of the evil. Resignation and discontent remained in our libraries.

Half a century before this, the philo- 
logian Fredrich Ritschl had already penetrated this problem of the library profession. As the real creator of the Bonn University library he had a clear insight into what it meant to work in a library when he said that enthusiasm comes through concentrating, not through scattering one's learning, and only the learning that one has worked for is of value. These words may have hit the nail on the head but libraries and librarians were not helped by them.

The occupational disease of librarians, the tendency toward the encyclopedic, is the final reason for personal discontent and technical disorder. On the other hand our ever increasing educational requirements have not even produced a competent technician, to say nothing of a librarian passionately devoted to his scholarly duties. Our catalogs of manuscripts are in disorder. With very few exceptions subject catalogs in the several libraries of Germany are either entirely lacking or are in large part in hopeless disarray. Even the fame of the Realkatalog of Goettingen has been for a century a thing of the past.

It is the same with that other field of learned activity, the purposeful building up of our collections. The outstanding jurist, Ernst Heymann in 1920 could without contradiction criticize the Minister of Education C. H. Becker because though the great Berlin library was able to purchase the most expensive works on ancient ivory sculpture, it ignored the field of foreign law.

Actually what was lacking in this richly endowed library was not so much the means as the people who knew the literature. Despite the most explicit regulations, employment was given to persons who were strangers to libraries, birds of passage and learned fugitives who looked upon the library as a way station on the road to an academic career. The profession was rootless.
"The whole man must move together" that is, all of a man's talents must be devoted to a single purpose. Even a highly developed education is only an introduction to knowledge and cannot give a profession form and substance that is true learning. A work is only fruitful or creative when it proceeds steadily from some point of concentration. In this sense even a simple peasant or laborer can be said to be educated.

The master is one who can limit his field. He is only found in special libraries, or in general libraries among the learned custodians of manuscripts, incunabula, orientalia, or the music collections. Tension remains the lot of the bulk of the profession.

Attempts of all sorts have been made to make library work more satisfying, not the least of which was through a sort of sublimation. The compilation of research bibliographies in an objectively limited field has often been suggested as a solution, but has no connection with the actual practice of the profession. Then after 1886 a number of professorships in library science were set up which only for a limited time aided posterity by adding to our objective knowledge, but did not affect the question of intellectual development which is central to the problem of the education of the librarian. Then came Ferdinand Eichler who wanted to develop library science into a science of values and library policy into world policy, a proposal so utterly unreal that Adolph von Harnack promptly attacked it in good set terms. But Harnack's own proposal for a professorship of the political economy of the book which would deal with the roles of the publishers, the book trade and the needs of scholarship showed itself likewise to be an unfruitful invention. Ortega y Gasset went even further. Already in the 18 th century the brilliant Lichtenberg was calling for a police force to patrol the world of

1 Lichtenberg, Georg C. Aphorismen. Ed. by A. 
books which was swelling beyond all sensible boundaries. It was the Spanish cultural philosopher though who first worked out the program in its details. He said that it was the job of the librarian to provide for the producing scholar all the necessary bibliographical information, that he should draw the attention of scholars to gaps in the literature that needed to be filled, that the librarian should prevent unnecessary works from ever being written, and finally that he should direct the reader in his reading. All these projects evaporated before the recognition of the simple fact that only in his own narrow field in which he himself is active can the librarian move with the authority of an expert.

Nonetheless the German journal Zentralblatt für Bibliothekswesen has taken up Ortega's plan of 1935 and latterly carried it even further. It speaks no longer of the matter of doing simple bibliographical spade work but of the duty to take a stand creatively and on the basis of research on all the intellectual, cultural and social questions of the day. It goes on to say that the librarian can survey as no other the progress of research and scholarship in which he must take part not only as a scholarly advisor but as a productive critic. It is immediately obvious that this overwhelming idealization of the librarian's job is not founded on the basis of reality.

The important thing is to train librarians for libraries, not for a romantic cultural policy. The emphasis is not to be found in the realm of imaginary duties but on the hard ground of reality and therefore it must be fundamental that the day-to-day job, the aliis inserviendo consumor, takes precedence over all others. But only the man with a background of successful practice can gain credence as a reformer. Whimsical suggestions have little place in cataloging or in planning buildings and even less determining the basic function of libraries.
Obviously it is likewise quite clear that a conscientious administrator alone is not qualified to direct a scholarly library, as even American experience has shown. Above and beyond the practical man we need a learned, technically trained librarian who first of all has mastered the literature of his own particular specialty but who from his own special studies has gone on to an understanding of neighboring fields and their functions and possibilities.

But is this not arguing for out-and-out dilettantism? The dilettante has a poor reputation among scholars. We refer the critics to the judgement of Goethe, Schopenhauer and Jakob Burckhardt about his real worth. The specialist who refuses to look beyond the bounds of his own specialty into the wide landscape of learning around him is to them no more than an ignoramus, a ruffian and a mill hand; indeed, Schopenhauer speaks of scholars who outside their own special fields were no better than cattle. Stated in terms less forceful but more elegant this means: he who understands only his own field does not even understand that. For true learning is not a matter of piling up facts about some detail but in giving the detail meaning and relating it to the whole. Every specialty is just a corner of the great realm of human knowledge, which admittedly can no longer be compassed by any one scholar. So much greater then is the need to bridge our way to neighboring disciplines. Every science needs the guidance and stimulation of its neighbors.

So it is that the great comprehensive fields of comparative philology, comparative religion and comparative anatomy and physiology, have arisen; and above and beyond these there has come into being the need ever anew to take a broad view of the whole state of the learning of the age. Every individual field of learning tends back into the unity of knowledge and draws from it sustenance. The confusion of Babel 
would be the result if every scholar kept to his field without reference to neighboring disciplines or to knowledge as a whole. Every science feels constantly the need to bring together its matter in textbooks and handbooks and in historical summaries because only in this abbreviated form can its significance be brought out.

There are indeed scholars who maintain that only the specialist is the true scientist, who call Ranke a novelist, and say that philosophy is the most superfluous of all the sciences. In the intellectual world these extreme though doubtless highly scholarly attitudes have no standing. Every really important scientist is to be found on the frontier of his specialty. David Hume is not only the greatest English philosopher, but also a great historian and political economist; Kant, a philosopher and a scientist; indeed all modern physics is pressing toward a new philosophical picture of the universe. One needs only to think of such names as Wilhelm von Humboldt, Franz Bopp, Jakob Grimm, and Viktor Hehn to realize how particularly in history in all of its branches including linguistics the fact of the inner coherence of all knowledge lies open to the day. And the greatest dilettante of all, the poet and government official Goethe, has long been accepted as a universal genius in whom after a century whole sciences find inspiration.

It is on this very ground of the unity in the diversity of the sciences that the librarian is most at home. This is his greatest strength, but also his weakness.

For the librarian, his intellectual curiosity stimulated on every side, runs the constant risk of learned dissipation and scientific busy work. Much more than the specialist he risks cloying and breaking his spirit through much reading until at last he ends in a sort of literary nihilism. "The librarian who reads is lost," is an old library saying. It is by no means unheard of for a librarian to retire from a career devoted to the narrow field of practical matters, and never again set foot inside his library, preferring rather to hunt and fish. The learning that impelled them did not lead to wisdom.

Memory work and knowledge of book titles is at best dead knowledge. At best it may be erudition, but it is never learning. This is what Lessing meant when he said, "I am not learned, I have never had any intention of becoming so-all I have ever tried to do is to be able in case of need to make use of a learned book." With characteristic acuteness he has described the art of reading so essential to a librarian.

A very gold mine on the art of reading is found in the letters and aphorisms of Lichtenberg. To this great psychologist proper reading was a problem of the first importance. He constantly returns to this question of the distinction between erudition and learning, with which the problem of wrong reading and right, of passive reading and active is so closely related.

The Göttingen professor Wilhelm Büttner, who though he was at the same time a natural historian and linguist, was Lichtenberg's prototype of the fact-crammed scholar. Though he was president of the Academy of Sciences, Lichtenberg said of him that there were few men who had less insight than he, and added "The man has read much but understands nearly everything wrong. He set up endless hypotheses ... but he is one of those people with whom one can talk by the hour without ever reaching a meeting of minds. He becomes fascinated by some new thing that he has read but never completely absorbs it ... he is more like a big dictionary full of errors than a philosopher." His library was the outward counterpart of himself. Goethe has left us a clear picture of it. After his death they found in a large room "laid out in groups as they had come all the books he had bought at auction. The bookcases were 
bulging and in the whole room one could scarcely find space to stand. On his old tottering chairs were piled bundles of books unopened the way they came from the bookstore, while the new flowed out over the old in layers and his decrepit furniture caved under the weight." His type in all its variants is still far from extinct.

The opposite to this urge to collect mere facts, the falsely encyclopedic, is real breadth of knowledge steeped in philosophy and inspired by it. The beginning of all knowledge is the recognition that one is ignorant, that all learning is but a patchwork, and what all the scientists in the world know is but a fragment of what is worth knowing, but that this fragment gets its great value when and only when it has coherence. It must be a part of me; I must experience it, not merely know it. I must absorb it into my being, it must be digested. The difference between knowledge and wisdom is like the difference between an imagined fire and a fire in which one has burned a finger.

If for an original thinker like Lichtenberg the art of reading was a continuous problem, how much greater problem it is for the librarian who by virtue of his profession stands in danger of trying to read at everything.

Multum legendum, sed non multa. It is better to know a little well, than to know much superficially. He who seeks for true learning does not read for distraction, to pass the time, rather he seeks to gain time through conscious selection.

The sources are more important to him than the literature derived from them. Whole epochs of the human mind have been from time to time condensed into a few smallish books, classics of their kind. Everyone knows their names and general outline, but a person deeply versed in them is not often met with. Across the centuries this literature reads to us at first a little strangely; only after we have worked at it for years does its meaning began to appear inexhaustible. The classics are few enough in number. Schopenhauer reckons only one out of every hundred thousand books to be great literature. Knowing them in the original is a tremendous advantage, for every language holds within it the whole thinking of a people.

But even in what seems at first the staggering immensity of the literature of pure science one can keep one's bearings. Here too for each discipline there are classics whose number is likewise not large. It is only the utter specialist who must have the latest edition. For our seeker after learning it is often the first edition which is important for it is in that form that the work appears in its proper historical context. These great ideas, which science takes and works over for decades and longer, have a special significance as they were first annunciated.

For anyone who advances from a familiarity with titles to a familiarity with ideas the picture of the state of human knowledge becomes easier to grasp; in the place of bewilderment and confusion there appears an intelligible system. For the librarian it is here-by the bye-that the great superiority of the classed catalog over the dictionary catalog becomes obvious.

This kind of education is not to be had in library courses or in introductions to academic studies, or even in the first assault on the world of books and learning, but comes only as the reward of hard work. It is no easily learned memory work but the result of experience; though there are some clues as to how to attain it.

Again Goethe, Schopenhauer and Jakob Burckhardt have thought the problem important enough to give their views on it. Goethe, for example, wrote to his son, a student at Heidelberg. "In your studies everything depends on whether you can remain master of your subject every step of the way. As soon as tradition gets beyond 
your control you will grow either dull or irritable and it is easy to be tempted to throw the whole thing over." What experience there is in those few words!

The way to meet the danger of overcharging the memory and thus losing elasticity is by making it a habit never to read except with pen in hand. Whatever seems noteworthy, whatever touches the nerve must be noted down. That is the simple receipt of as great a scholar as Jakob Burckhardt. One lays up files of notes first for one's general education and a second more detailed series for special studies. These files were what Lichtenberg called his money boxes. But without some sort of a subject index these notes would soon fade from the memory.

Those even more intellectually inclined should follow Lichtenberg's practice in reading to set down in a few words the author's purpose and his chief thoughts. He said that in every book there must be a spiritus rector, a guiding theme, or the book is not worth a penny, and it is for the reader to discover what it is. He who reads thus is well employed and gains something. There is a kind of reading, he added, whereby the mind does not gain, but rather loses, reading that is done uncritically. This is passive reading. There are times when the whole contents of a thick book can be compressed into two or three words, as in Schopenhauer's or Darwin's chief works.

$\mathrm{He}$ who is in the habit of reading purposefully can look upon "desultory reading" to use Lichtenberg's phrase, or "reading by the minute" to use Goethe's, as his greatest pleasure, though for others less well equipped, this leads only to emptiness and waste.

A good ear for the language and the style of a book is an almost infallible compass on the sea of literature. Uncertain, vacillating, unclear language is evidence of thinking of the same sort. Whether an expression fits like a glove or only half applies is immediately obvious to the careful reader.

A carefully selected personal library is furthermore the essential beginning for the education of a librarian. The librarian must always have his own special literature in the best editions at hand. Biographies of scholars, histories of the various branches of learning, above all philosophy, the literatures for example in the great form of Hermann Hettner, introductions to the branches of learning such as Wilhelm Wundt or Friedrich Paulsen for philosophy, or Paul Wernle for theology, and the classics of each great discipline go to make up the content of the librarian's library. Even in cheap second-hand editions they are suffcient to create the proper scientific historical atmosphere. A rich source for understanding scientific trends and results is found in prefaces and even more in the lectures and Festreden (learned addresses on special occasions) in the publications of learned societies, biographical memoirs, in Rektoratsreden (scientific presidential addresses) without number and in the collections of shorter works that give in popular form the essence of the work of all the leading scholars. Not to be neglected are the German readers by Wilhelm Wackernagel, Adalbert Stifter, Hermann Bächtold, Hermann Masius, Hugo von Hofmannsthal, and Eduard Korrodi with their short selections and glances at the peaks of literature. Hermann Hesse and particularly Martin Bodmer in their books on world literature open an even wider perspective, which give one so much more than mere knowledge of book titles. Here we are in the realm of the higher development of the mind. In the words of Shakespeare's Prospero, "Mine own library with volumes that I prize above my dukedom." 2

In a fundamental study Konrad Fiedler found the origin of artistic activity not in

${ }^{2}$ The Tempest I: 2 . 
any special manner of viewing things, but in the necessity of actively expressing oneself about Nature. Only in this way does real genius manifest itself. The merely passive point of view is the clear mark of failing talent. It is the same with an author's use of language. The thought and the language cannot be separated. Only when a thought has found expression in speech does it become personal and tangible. Knowledge must have roots. "We know a thing only insofar as we can express it," as Novalis wrote. Good expression is no more than the evidence of good thinking. An unclear thought is expressed in unclear speech.

The formulation of a thought belongs just as much to man's fundamental need for spiritual autonomy as the setting down in writing of a word, a word which disappears like a breath. Even a shy man can be eloquent in his own field. The word does not follow after the thought as something secondary, but is related to it in the closest way. "Everyone who has ever done any writing has found that the very act of writing awakes in one something that one never clearly recognized even though it had lain in him all the time."

That is the explanation of the significance of the literary remains of great writers and scholars. Even apparently unimportant fragments when brought together, can become valuable. For example, among Jakob Burckhardt's papers, there were found some papers on the history of art which he had prepared for publication simply to clarify his own thinking on certain matters. Lichtenberg had the habit for decades of noting down without any sort of order the most fleeting thoughts in his old copybook, even some mere turn of phrase he would preserve in this way. But no work of any consequence is ever produced by sleight of hand, and even the greatest artist needs a note book.

No one who understands the situation would demand of a librarian, busy with work for others, that he should produce any lengthy scientific work. Milkau with one stroke gained the reputation of a finished author on librarianship by one not very long but carefully written essay on the state and history of scientific libraries, which appeared in a big collection. The librarian should never withdraw into self-chosen learned loneliness, but should expose for public criticism the results of his wide reading. That is the keystone of the true librarian.

By sound tacit agreement there is no rank among the sciences. The time is past when one librarian of long service could dare to describe as mere affectation the study of incunabula now so important to the cultural history of the late Middle Ages. The complete devotion of the author to his theme is decisive. With every seriously conducted work in his own field the librarian can achieve self-respect and the general respect of others.

There are certain tasks in the field of learning that can be done by no one better than the librarian. Their variety is great. The German and foreign professional journals, the handbooks founded by Svend Dahl and Milkau give an idea of the variety and breadth that subjects can cover. Even the apparently simplest technical publication especially in its historical and comparative setting can be fascinating and of critical importance over the decades as faulty catalogs and badly planned buildings have shown clearly enough.

Every librarian must know the history of his institution and especially the development of its collections from the sourcesthat is, from direct observation. The history of an individual library is a part of the general history of libraries, which in turn is an important part of the history of learning. The history of learning leads into the science of the sciences and therewith to the summation of the knowledge of which man is capable. 